\title{
IMPLEMENTASI PENDIDIKAN KARAKTER PADA SISWA MADRASAH ALIYAH
}

\author{
Siti Asdiqoh dan Badrus Zaman \\ Institut Agama Islam Negeri Salatiga
}

Abstract: Implementation of character education for students at MAN 1 Boyolali using the Holistic Model that all citizens ranging from teachers, employees, students, and the school community must be involved and responsible for the implementation of character education by taking into account three design bases in its implementation. Class-based character education design, school culturebased character education design, and community-based character education design. The basic characters of students who are on average are good, so they can adjust to the character education model at MAN 1 Boyolali. An education curriculum that supports character education at MAN 1 Boyolali. Democratic culture that supports character education that is becoming a habit in the classroom, school environment and school community includes: school committees, parents of students, and alumni. The "Nurun" culture is still very high, without knowing the origins of the solution. The number of tasks that must be completed by students every day, both academic assignments and the task of intracuricular and extracurricular organizations. Misuse of cellphones and gadgets in the classroom and school environment. Lack of opportunities for mutual communication and coordination between the school and the school committee, parents, and alumni.

Keywords: Implementation Model, Character Education

Abstrak: Implementasi pendidikan karakter pada siswa di MAN 1 Boyolali menggunakan Model Holistik yaitu seluruh warga mulai dari guru, karyawan, siswa, serta komunitas sekolah harus terlibat dan bertanggung jawab terhadap pelaksanaan pendidikan karakter dengan memperhatikan tiga basis desain dalam implementasinya. Desain pendidikan karakter berbasis kelas, desain pendidikan karakter berbasis kultur sekolah, dan desain pendidikan karakter berbasis komunitas. Karakter dasar siswa yang rata-rata baik, sehingga dapat menyesuaikan diri dengan model pendidikan karakter di MAN 1 Boyolali. Kurikulum pendidikan yang mendukung pendidikan karakter di MAN 1 Boyolali. Budaya demokratis yang mendukung pendidikan karakter yang menjadi kebiasaan di kelas, lingkungan sekolah dan komunitas sekolah meliputi: komite sekolah, orang tua siswa, dan alumni. Budaya "Nurun" masih sangat tinggi, tanpa tau asal muasal cara penyelesaiannya. Banyaknya tugas yang harus diselesaikan siswa setiap harinya, baik tugas akademik maupun tugas organisasi intrakurikuler maupun ekstrakurikuler. Penyalahgunaan HP dan gadget di lingkungan kelas dan 
sekolah. Kurangnya kesempatan untuk saling berkomunikasi dan koordinasi antara pihak sekolah dengan komite sekolah, orang tua siswa, dan alumni.

\section{Kata Kunci: Model Implementasi, Pendidikan Karakter}

\section{A. PENDAHULUAN}

Pengertian pendidikan dapat dilihat pada Undang-Undang RI No 20 Tahun 2003, tentang sistem pendidikan nasional yang berbunyi: Pendidikan nasional berfungsi mengembangkan kemampuan dan membentuk watak yang bermartabat dalam rangka mencerdaskan kehidupan bangsa yang bertujuan untuk berkembangnya peserta didik agar menjadi manusia yang berilmu, beriman dan bertakwa kepada Allah SWT, berakhlak mulia, kreatif, cakap, mandiri dan menjadi warga negara yang bertanggung jawab. Pendidikan yang dilaksanakan pada prinsipnya semua sama, yaitu memberi bimbingan agar dapat hidup mandiri sehingga dapat meneruskan dan melestarikan tradisi yang hidup di masyarakat. Dalam kaitannya dengan tujuan pendidikan nasional tersebut sejalan dengan tujuan yang dikehendaki oleh pendidikan agama. Adapun tujuan pendidikan agama antara lain: Membentuk prilaku manusia yang bertakwa kepada Allah SWT, diperlukan adanya bimbingan, tujuan pendidikan Islam itu adalah mendidik dan mengarahkan manusia kepada jalan Allah SWT, sebab dalam pendidikan mencakup aspek kehidupan manusia di dunia dan di akhirat (Badrus Zaman, 2018: 130).

Ada indikasi kuat mengenai hilangnya nilai-nilai luhur yang melekat pada bangsa kita, seperti kejujuran, kesantunan, dan kebersamaan, cukup menjadikan keprihatinan kita bersama. Harus ada usaha untuk menjadikan nilai-nilai itu kembali menjadi karakter yang kita banggakan di hadapan bangsa lain. Salah satu upaya ke arah itu adalah memperbaiki sistem pendidikan kita harus menitikberatkan pada pendidikan karakter yang berlandaskan falsafah bangsa Indonesia yaitu Pancasila. Membangun karakter bangsa membutuhkan waktu yang lama dan harus dilakukan secara berkesinambungan. Pemerintah kita, yang diwakili oleh Kementerian Pendidikan Nasional tiada henti-hentinya melakukan upaya-upaya untuk perbaikan kualitas pendidikan di Indonesia, namun belum semuanya berhasil, terutama menghasilkan insan Indonesia yang berkarakter. Salah satu upaya untuk mewujudkan pendidikan seperti di atas, para peserta didik (siswa dan mahasiswa) harus dibekali dengan pendidikan khusus yang membawa misi pokok dalam pembinaan karakter/akhlak mulia.

Arah dan tujuan pendidikan nasional kita, seperti diamanatkan oleh UUD 1945, adalah peningkatan iman dan takwa serta pembinaan akhlak mulia para peserta didik yang dalam hal ini adalah seluruh warga negara yang mengikuti proses pendidikan di Indonesia. Karena itu, pendidikan yang membangun nilai-nilai moral atau karakter di kalangan peserta didik harus selalu mendapatkan perhatian. Pendidikan karakter dari kanak-kanak (TK-Mahasiswa) merupakan wadah yang sangat penting untuk mempersiapkan sejak dini para generasi penerus yang nantinya akan menjadi pemimpin bangsa kita di masa datang. Pendidikan karakter menurut Thomas Lickona (2013: 51) mengandung tiga unsur pokok yaitu mengetahui kebaikan (knowing the good), 
mencintai kebaikan (desiring the good), dan melakukan kebaikan (doing the good). Pendidikan karakter tidak sekedar mengajarkan mana yang benar dan mana yang salah kepada anak, tetapi lebih dari itu pendidikan karakter menanamkan kebiasaan (habituation) tentang yang baik sehingga peserta didik paham, mampu merasakan, dan mau melakukan yang baik. Pendidikan karakter ini membawa misi yang sama dengan pendidikan akhlak atau pendidikan moral.

Pendidikan karakter adalah usaha sadar manusia untuk mengembangkan keseluruhan dinamika relasional antar pribadi dengan berbagai macam dimensi, baik dari dalam maupun dari luar dirinya, agar pribadi itu semakin dapat menghayati kebebasannya sehingga ia dapat semakin bertanggung jawab atas pertumbuhan dirinya sendiri sebagai pribadi dan perkembangan orang lain dalam hidup mereka berdasarkan nilai-nilai moral yang menghargai kemartabatan manusia (Doni Koesoema A, 2012: 57). Ada 18 karakter bangsa yang menjadi target sekaligus indikator keberhasilan pendidikan karakter bagi bangsa meliputi: 1) Religius, 2) Jujur, 3) Toleransi, 4) Disiplin, 5) Kerja keras, 6) Kreatif, 7) Mandiri, 8) Demokratis, 9) Rasa ingin tahu, 10) Semangat kebangsaan, 11) Cinta tanah air, 12) Menghargai prestasi, 13) Bersahabat/Komunikatif, 14) Cinta damai, 15) Gemar membaca, 16) Peduli lingkungan, 17) Peduli sosial, dan 18) Tanggung jawab (Badrus Zaman, 2019: 27).

Penyelenggaraan pendidikan di suatu sekolah dimaksudkan untuk menghasilkan lulusan yang memiliki karakter, kecakapan, keterampilan, dan pengetahuan yang memadai untuk mengembangkan potensi diri secara optimal, sehingga lulusan memiliki ketahanan dan keberhasilan dalam pendidikan lanjutan, serta kehidupan yang selalu berubah sesuai dengan perkembangan zaman. Sehingga apabila pendidik salah dalam penanganannya maka output yang dihasilkan tidak sesuai dengan tujuan pendidikan nasional. Salah satu lembaga pendidikan yang menerapkan pendidikan karakter siswa adalah MAN I Boyolali. Selain unggul dalam hal karakter, MAN I Boyolali juga unggul dalam bidang akademik. Terbukti dengan banyak piala penghargaan dan kejuaraan yang telah diraih siswa-siswi serta guru-gurunya. Lembaga pendidikan tersebut banyak diincar masyarakat untuk dapat menyekolahkan anaknya. Bukan hanya masyarakat Boyolali saja yang menimba ilmu di sana, akan tetapi juga daerah-daerah lain sekitarnya termasuk dari luar wilayah Boyolali, seperti Kabupaten Semarang, Klaten, dan Sukoharjo.

Dari hasil observasi setiap pagi, tepatnya pukul 07.00 WIB para guru dan siswa sudah berada di sekolah. Kegiatan yang dilakukan setiap pagi sebelum kegiatan belajar dimulai adalah ketika datang guru sudah berjajar dan siswa yang datang berjabat tangan kemudian semua siswa berbaris rapi dan membacakan ikrar siswa dan dilanjutkan membaca Al-Qur'an. Pada istirahat pertama siswa dan guru melakukan salat Duha dan siang hari ketika istirahat kedua melakukan salat Zuhur berjamaah. Bahkan tanpa diperintah oleh guru, siswa MAN I Boyolali sudah aktif melakukan kegiatan rutinitas yang sudah menjadi tradisi lembaga tersebut. Sekolah yang menjadi tempat belajar para siswanya harus dikelola dengan sebaik-baiknya sehingga menjadi sekolah yang 
bermutu. Sekolah dikatakan bermutu baik apabila mampu mengemban misinya dalam rangka mencapai tujuan kelembagaannya.

\section{B. METODE}

Penelitian ini merupakan penelitian kualitatif. Dalam penelitian kualitatif data yang dikumpulkan bukan angka-angka, akan tetapi berupa kata-kata atau gambaran. Data yang dimaksud berasal dari wawancara, catatan lapangan, foto, dokumen pribadi dan lainnya (Lexy J. Moleong, 2010: 11). Oleh karena itu dalam penelitian ini menggunakan pendekatan deskriptif. Penelitian deskriptif merupakan penelitian yang menggambarkan fenomena atau populasi tertentu yang diperoleh peneliti dari subjek yang berupa individu, organisasional atau perspektif yang lain. Adapun tujuannya adalah untuk menjelaskan aspek yang relevan dengan fenomena yang diamati dan menjelaskan karakteristik fenomena atau masalah yang ada.

Sesuai dengan tema yang peneliti bahas, penelitian ini menggunakan jenis penelitian lapangan (Field Research), dimana penelitian ini dilakukan langsung di lapangan yaitu di MAN I Boyolali untuk mendapatkan data-data yang diperlukan. Peneliti mengadakan pengamatan tentang suatu fenomena dalam suatu keadaan alamiah. Peneliti lapangan biasanya membuat catatan lapangan secara ekstensif yang kemudian dibuatkan kode dan dianalisis dalam berbagai cara

\section{MODEL IMPLEMENTASI PENDIDIKAN KARAKTER \\ 1. Model TADZKIRAH}

Tunjukkan Teladan: Guru harus menjadi teladan bagi peserta didik. Guru harus memiliki sifat tertentu sebab guru ibarat naskah asli yang hendak dikopi. Arahkan (Berikan Bimbingan): Bimbingan orang tua kepada anaknya, guru kepada muridnya perlu diberikan dengan memberikan alasan, penjelasan, pengarahan, dan diskusidiskusi. Juga bisa dilakukan dengan teguran, mencari tahu penyebab masalah dan kritikan sehingga tingkah laku anak berubah. Dorongan (Berikan Motivasi/Reinforcement): Guru harus mampu memotivasi peserta didiknya agar peserta didik bersedia dan mau mengerjakan kegiatan atau perilaku yang diharapkan gurunya. Zakiyah (murni/bersih-tanamkan niat yang tulus): guru mempunyai fungsi dan peran cukup signifikan, dituntut untuk senantiasa memasukkan nilai-nilai batiniah kepada anak dalam proses pembelajaran. Kontinuitas (sebuah proses pembiasaan untuk belajar, bersikap dan berbuat). Ingatkan: guru harus berusaha mengingatkan kepada anak bahwa mereka diawasi oleh Allah yang mengetahui yang tersembunyi walaupun tersirat di dalam hati, sehingga ia akan senatiasa mengingat-Nya dan menjaga perilakunya dari perbuatan tercela. Sehingga iman yang telah ditanamkan Allah di dalam hati akan di bawa dari potensialitas menuju aktualitas. Repetisi (pengulangan): pendidikan yang efektif dilakukan dengan berulang kali sehingga anak menjadi mengerti. Pelajaran atau nasihat apapun perlu dilakukan secara berulang, sehingga mudah dipahami. 
$\mathbf{A}=(\mathbf{O})$ Organisasikan: guru harus mampu mengorganisasikan pengetahuan dan pengalaman yang sudah diperoleh siswa di luar sekolah dengan pengalaman belajar yang diberikannya. Pengorganisasian yang sistematis dapat membantu guru untuk menyampaikan informasi dan mendapatkan informasi secara cepat. Informasi tersebut kemudian dijadikan sebagai umpan balik untuk kegiatan belajar yang sedang dilaksanakan. Heart-Hati (Sentuhlah Hatinya): Niat, ikhlas dan ridha itu ada di dalam hati, dan itu akan lahir manakala hatinya disentuh (Abdul Majid dan Dian Andayani, 2012: 117).

\section{Model Istiqomah}

Imagination: guru harus mampu mengajar dengan membangkitkan imajinasi jauh ke depan, baik itu manfaat ilmu, maupun menciptakan teknologi dari yang tidak ada menjadi ada guna kemakmuran manusia. Student Centre: peserta didik sebagai pusat aktivitas belajar. Teknologi: guru sebaiknya dapat memanfaatkan teknologi belajar multi inderawi, sehingga membuat anak senang dalam belajar dan informasi dapat dengan mudah di panggil kembali (recall). Intervention: guru harus mampu mendesain proses intervensi terstruktur pada peserta belajar. Question and Answer: guru harus mampu mengajar dengan cara mendorong rasa ingin tahu, merumuskan pertanyaan rasa ingin tahu (hipotesa), merancang cara menjawab rasa ingin tahu, dan menemukan jawaban. Jawaban akhir adalah ilmu, perbendaharaan dan kosa kata yang dimiliki. Organisation: guru sebaiknya turut mengontrol pola pengorganisasian ilmu yang telah diperoleh oleh peserta belajar. Motivation: untuk dapat memberi motivasi seorang guru harus memiliki motivasi lebih. Motivasi sangat dipengaruhi oleh aspek emosi. Application: puncaknya ilmu adalah amal. Heart: hepar, jantung hati, spiritual; kekuatan spiritual terletak pada kelurusan dan kebersihan hati nurani, roh, pikiran, jiwa dan emosi (Abdul Majid dan Dian Andayani, 2012: 142-144).

\section{Model Iqra-Fikir-Dzikir}

Inquiri: penyelidikan, belajar mandiri dengan menggali apa yang kita lihat, dengar, baca, perhatikan, alami, dan rasakan. Question: bertanya, belajar yang tumbuh dalam diri adalah untuk memenuhi rasa ingin tahu. Melakukan konfirmasi, menyusun hipotesa terus bertanya dalam memenuhi rasa ingin tahunya. Repeat: mengulang, melakukan review terhadap apa yang telah diterima, karena hal ini dimaksudkan untuk menyimpan data dari memori jangka pendek ke jangka panjang. Action: puncaknya belajar adalah amal, apa yang telah kita pahami perlu diaplikasikan. Fun: belajar untuk mengaktualisasikan diri sebagai individu dengan kepribadian yang memiliki timbangan dan tanggung jawab pribadi. Terciptanya suatu kegiatan belajar yang menyenangkan, tidak tertekan, gembira, flow dan enjoy. Ijtihad: pintu ijtihad, kreatifitas dan inovasi terbuka dalam Islam. Kita akan berada pada puncak belajar ketika mampu melakukan sintesa atas seluruh kerangka pemikiran yang telah kita miliki, kemudian muncul ide baru yang unik. Konsep: belajar mengumpulkan konsep, rumusan, model, pola dan teknik, sebagai dasar untuk mengembangkannya dalam konteks yang lebih luas. 
Imajinasi: imajinasi dapat menghadirkan yang baru yang asalnya tidak ada menjadi ada. Belajar membangun imajinasi untuk menciptakan sesuatu yang benar-benar baru. Rapi: jika ingin sukses, maka biasakan dengan catatan yang baik serta mampu mengorganisasikan materi dengan baik. Dengan demikian guru harus mampu mendorong peserta didik untuk memiliki catatan yang rapi, lengkap, dan baik. DZIKIR: menerapkan Dzikir, yang merupakan makna dari fikir. Dzikir dalam hal ini diartikan sebagai Do'a, Ziarah, Iman, Komitmen, Ikrar, dan Realitas (Abdul Majid dan Dian Andayani, 2012: 144-147).

\section{Model Holistik}

Model Holistik adalah seluruh warga mulai dari guru, karyawan, para peserta didik harus terlibat dan bertanggung jawab terhadap pelaksanaan pendidikan karakter. Hal yang paling penting di sini adalah bahwa pengembangan karakter harus terintegrasi ke dalam setiap aspek kehidupan sekolah (Muchlas Samani dan Hariyanto, 2012: 139). Hal di atas menunjukkan bahwa pendidikan karakter harus memperhatikan tiga basis desain dalam implementasinya, yaitu:

a. Desain pendidikan karakter berbasis kelas.

b. Desain pendidikan karakter berbasis kultur sekolah.

c. Desain pendidikan karakter berbasis komunitas (Ulil Amri Syarif, 2012: 73).

\section{Model Komprehensif}

\section{a. Inkulkasi Nilai}

Inkulkasi (penanaman) Nilai memiliki ciri-ciri sebagai berikut: Mengomunikasikan kepercayaan disertai alasan yang mendasarinya, Memperlakukan orang lain secara adil, menghargai pandangan orang lain, mengemukakan keragu-raguan atau perasaan tidak percaya disertai dengan alasan, dan dengan rasa hormat, menciptakan pengalaman sosial dan emosional mengenai nilai-nilai yang dikehendaki, tidak secara ekstrim, membuat aturan, memberikan penghargaan, dan memberikan konsekuensi disertai alasan. Yang tetap membuka komunikasi dengan pihak yang tidak setuju dan memberikan kebebasan bagi adanya perilaku yang berbeda-beda, apabila sampai pada tingkat yang tidak dapat diterima, diarahkan untuk memberikan kemungkinan berubah (Darmiati Zuchdi dkk, 2012: 35-36).

\section{b. Keteladanan Nilai}

Dalam pendidikan nilai dan spiritualitas, pemodelan atau pemberian teladan merupakan strategi yang biasa digunakan. Untuk dapat menggunakan strategi ini, ada dua syarat yang harus dipenuhi, yaitu: guru atau orang tua harus berperan sebagai model yang baik bagi peserta didik atau anak-anaknya, peserta didik atau anak-anak harus meneladani orang-orang yang terkenal yang berakhlak mulia, terutama nabi Muhammad SAW dan para nabi lain bagi yang beragama Islam (Darmiati Zuchdi dkk, 2012: 36).

\section{c. Fasilitasi Nilai}


Inkulkasi (penanaman/internalisasi) dan keteladanan mendemonstrasikan kepada subjek cara yang terbaik untuk mengatasi berbagai masalah, sedangkan fasilitasi melatih subjek didik mengatasi masalah-masalah tersebut. Bagian yang terpenting dalam metode fasilitasi ini adalah pemberian kesempatan kepada subjek didik. Menurut Kirschenbaum dalam Darmiati Zuchdi dkk (2012: 37-38) kegiatan-kegiatan yang dilakukan oleh subjek didik dalam pelaksanaan metode fasilitasi membawa dampak positif pada perkembangan kepribadian.

\section{d. Pengembangan Keterampilan (Soft Skills)}

Ada berbagai keterampilan yang diperlukan agar seseorang dapat mengamalkan nilai-nilai yang dianut, sehingga berperilaku konstruktif dan bermoral dalam masyarakat. Keterampilan tersebut antara lain: berpikir kritis, berpikir kreatif, berkomunikasi secara jelas, menyimak, bertindak asertif, dan menemukan resolusi konflik (Darmiati Zuchdi dkk, 2012: 38).

\section{IMPLEMENTASI PENDIDIKAN KARAKTER}

Berdasarkan hasil wawancara pada tanggal 7 September 2019 dengan Bapak Muslih, selaku kepala sekolah, menyatakan implementasi pendidikan karakter di MAN 1 Boyolali menggunakan Model Holistik dengan memperhatikan tiga basis desain dalam implementasinya, yaitu desain pendidikan karakter berbasis kelas, desain pendidikan karakter berbasis kultur sekolah, dan desain pendidikan karakter berbasis komunitas. Hal ini senada dengan apa yang disampaikan oleh Bapak Abdul Rohim selaku Waka Kurikulum yakni:

Implementasi pendidikan karakter pada siswa di MAN 1 Boyolali menggunakan Model Holistik yaitu seluruh warga mulai dari guru, karyawan, siswa, serta komunitas sekolah harus terlibat dan bertanggung jawab terhadap pelaksanaan pendidikan karakter dengan memperhatikan tiga basis desain dalam implementasinya, yaitu: desain pendidikan karakter berbasis kelas, desain pendidikan karakter berbasis kultur sekolah, dan desain pendidikan karakter berbasis komunitas (Wawancara 7 September 2019).

Terkait desain pendidikan karakter berbasis kelas, berdasarkan wawancara dengan Ibu Warsiti, yaitu: Kompetensi guru sangat baik sehingga guru dapat melaksanakan peran sebagai fasilitator, pendamping, motivator, pembimbing, serta teladan bagi siswa dalam proses pembelajaran berjalan dengan optimal. Dan dalam proses pembelajaran, metode pembelajaran lebih banyak menggunakan metode kerja sama dan pemecahan masalah di kelas (Wawancara 14 September 2019). Menurut Bapak Wasul, selaku guru Agama, desain pendidikan karakter berbasis kelas pada siswa di MAN I Boyolali yaitu: Guru menggunakan sistem pembelajaran dialog bukan monolog (Wawancara 14 September 2019). 
Sedangkan menurut Ibu Ikjisi, selaku guru program IPS, desain pendidikan karakter berbasis kelas pada siswa di MAN I Boyolali yaitu: Guru mengajarkan sikap demokratis dan rasa tanggung jawab, pada pertemuan pertama pembelajaran menyepakati kontrak belajar dengan siswa serta pemilihan pengurus kelas secara demokratis. Membiasakan siswa untuk mengemukakan pendapat, saling menghargai dan menghormati perbedaan (Wawancara 14 September 2019). Hal senada diungkapkan oleh Bapak Abdul Rohim, faktor pendukung implementasi pendidikan karakter pada siswa di MAN I Boyolali adalah: Guru harus mempunyai 4 kompetensi untuk melaksanakan peran sebagai fasilitator, pendamping, motivator, pembimbing, serta teladan bagi siswa dalam proses pembelajaran secara optimal, guru menggunakan sistem pembelajaran dialog bukan monolog, metode pembelajaran lebih banyak menggunakan metode kerja sama dan pemecahan masalah di kelas, guru mengajarkan sikap demokratis dan rasa tanggung jawab yaitu, pada pertemuan pertama pembelajaran menyepakati kontrak belajar dengan siswa serta pemilihan pengurus kelas secara demokratis, serta membiasakan siswa untuk mengemukakan pendapat, saling menghargai dan menghormati perbedaan yang ada di kelas (Wawancara 21 September 2019).

Selanjutnya, Bapak Muslih juga menjelaskan desain pendidikan karakter berbasis kultur sekolah, meliputi: Memberikan apresiasi kepada siswa yang berprestasi akademik maupun non akademik dengan uang pembinaan dan beasiswa peringkat 1 beasiswa gratis SPP 5 bulan, peringkat 2 beasiswa gratis SPP 3 bulan, dan peringkat 3 beasiswa gratis 2 bulan (Wawancara 7 September 2019). Hal senada disampaikan oleh Samsul Arifin selaku ketua OSIS MAN 1: Bahwa siswa yang dapat berprestasi baik di bidang akademik maupun non akademik di apresiasi dengan uang pembinaan dan beasiswa peringkat 1 beasiswa gratis SPP 5 bulan, peringkat 2 beasiswa gratis SPP 3 bulan, dan peringkat 3 beasiswa gratis 2 bulan (Wawancara 21 September 2019).

Bapak Abdul Rohim menambahkan terkait desain pendidikan karakter berbasis kultur sekolah yaitu: Dengan menumbuhkan budaya demokratis di MAN 1 Boyolali dengan membiasakan siswa untuk mengemukakan pendapat, saling menghargai dan menghormati perbedaan, serta membangun budaya demokratis dengan PEMILU OSIS, dan pada acara MOS pendidikan karakter dimasukkan dalam materi pembekalan siswa baru. Sedangkan apresiasi pada guru dan karyawan yaitu dengan uang pembinaan serta dikirim mengikuti diklat, workshop membuat karya ilmiah dan sebagainya (Wawancara 7 September 2019). Sedangkan Desain pendidikan karakter berbasis komunitas, Bapak Muslih menjelaskan ada 3 komunitas yang berkaitan dengan implementasi pendidikan karakter di MAN 1 Boyolali meliputi: Komunitas komite sekolah, komunitas orang tua, dan komunitas alumni (Wawancara 7 September 2019).

Kegiatan dan dukungan terkait implementasi pendidikan karakter di MAN 1 Boyolali, menurut Bapak Abdul Rohim didukung sepenuhnya oleh 3 komunitas ini yaitu: Dengan memberikan usulan dan saran yang membangun terkait program pendidikan karakter yang di implementasikan di MAN 1 Boyolali, selain itu juga alumni melaksanakan kegiatan-kegiatan reuni dan amal dengan nama Alumni MAN Peduli 
untuk masyarakat miskin dan keluarga alumni yang membutuhkan (Wawancara 7 September 2019).

\section{FAKTOR PENDUKUNG DAN PENGHAMBAT IMPLEMENTASI PENDIDIKAN KARAKTER}

Terkait faktor pendukung implementasi pendidikan karakter pada siswa di MAN I Boyolali, berdasarkan wawancara dengan Ibu Warsiti, selaku guru program IPA, yaitu: Adanya fasilitas buku pegangan yang disediakan perpustakaan yang lengkap untuk 3 program IPA, IPS, dan Agama. Kompetensi guru yang baik, sehingga dapat menjadi fasilitator, pendamping, motivator, pembimbing, serta teladan bagi siswa dalam proses pembelajaran (Wawancara 14 September 2019). Menurut Bapak Wasul, selaku guru program Agama, faktor pendukung implementasi pendidikan karakter pada siswa di MAN I Boyolali adalah: Karakter dasar siswa yang rata-rata baik, sehingga dapat menyesuaikan diri dengan model pendidikan karakter di MAN 1 Boyolali (Wawancara 14 September 2019).

Sedangkan menurut Ibu Ikjisi, selaku guru program IPS, faktor pendukung implementasi pendidikan karakter pada siswa di MAN I Boyolali adalah: Kurikulum pendidikan yang mendukung pendidikan karakter di MAN 1 Boyolali. Budaya demokratis yang mendukung pendidikan karakter yang menjadi kebiasaan di kelas, lingkungan sekolah dan komunitas sekolah meliputi komite sekolah, orang tua siswa, dan alumni (Wawancara 14 September 2019). Hal senada diungkapkan oleh Bapak Abdul Rohim, faktor pendukung implementasi pendidikan karakter pada siswa di MAN I Boyolali adalah: Adanya fasilitas buku pegangan yang disediakan perpustakaan yang lengkap untuk 3 program IPA, IPS, dan Agama. Kompetensi guru yang baik, sehingga dapat menjadi fasilitator, pendamping, motivator, pembimbing, serta teladan bagi siswa dalam proses pembelajaran. Karakter dasar siswa yang rata-rata baik, sehingga dapat menyesuaikan diri dengan model pendidikan karakter di MAN 1 Boyolali. Kurikulum pendidikan yang mendukung pendidikan karakter di MAN 1 Boyolali. Budaya demokratis yang mendukung pendidikan karakter yang menjadi kebiasaan di kelas, lingkungan sekolah dan komunitas sekolah meliputi komite sekolah, orang tua siswa, dan alumni (Wawancara 7 September 2019).

Terkait faktor penghambat implementasi pendidikan karakter pada siswa di MAN I Boyolali. Berdasarkan wawancara dengan Ibu Warsiti, selaku guru program IPA, yaitu: Budaya "Nurun" masih sangat tinggi, tanpa tahu asal muasal cara penyelesaiannya. Banyaknya tugas yang harus diselesaikan siswa setiap harinya, baik tugas akademik maupun tugas organisasi intrakurikuler maupun ekstrakurikuler (Wawancara 14 September 2019). Hal senada di ungkapkan oleh Samsul Arifin, faktor penghambat implementasi pendidikan karakter pada siswa di MAN I Boyolali adalah budaya "Nurun" masih sangat tinggi, tanpa tahu asal muasal cara penyelesaiannya. Banyaknya tugas yang harus diselesaikan siswa setiap harinya, baik tugas akademik maupun tugas organisasi intrakurikuler maupun ekstrakurikuler (Wawancara 21 September 2019). 
Menurut Bapak Wasul, selaku guru program Agama, faktor penghambat implementasi pendidikan karakter pada siswa di MAN I Boyolali adalah: Penyalahgunaan HP dan gadget di lingkungan kelas dan sekolah (Wawancara 14 September 2019). Sedangkan menurut Ibu Ikjisi, selaku guru program IPS, faktor penghambat implementasi pendidikan karakter pada siswa di MAN I Boyolali adalah: Pengaruh negatif dari lingkungan pergaulan siswa di luar sekolah (Wawancara 14 September 2019). Bapak Abdul Rohim menyatakan, faktor penghambat implementasi pendidikan karakter pada siswa di MAN I Boyolali adalah: Kurangnya kesempatan untuk saling berkomunikasi dan berkoordinasi antara pihak sekolah dengan komite sekolah, orang tua siswa, dan alumni (Wawancara 7 September 2019). Hal yang sama diungkapkan oleh Ibu Daimatun, selaku komite sekolah, faktor penghambat implementasi pendidikan karakter pada siswa di MAN I Boyolali adalah adanya kendala waktu dan jarangnya kesempatan untuk saling berkomunikasi dan berkoordinasi antara pihak sekolah dengan komite sekolah, orang tua siswa, dan alumni (Wawancara 21 September 2019).

\section{SIMPULAN}

Dari hasil penelitian implementasi pendidikan karakter pada siswa di MAN 1 Boyolali menggunakan Model Holistik yaitu seluruh warga mulai dari guru, karyawan, siswa, serta komunitas sekolah harus terlibat dan bertanggung jawab terhadap pelaksanaan pendidikan karakter dengan memperhatikan tiga basis desain dalam implementasinya, yaitu: desain pendidikan karakter berbasis kelas, desain pendidikan karakter berbasis kultur sekolah, dan desain pendidikan karakter berbasis komunitas. Faktor pendukung implementasi pendidikan karakter pada siswa di MAN I Boyolali, yaitu adanya fasilitas buku pegangan yang disediakan perpustakaan yang lengkap untuk 3 program IPA, IPS, dan Agama. Kompetensi guru yang baik, sehingga dapat menjadi fasilitator, pendamping, motivator, pembimbing, serta teladan bagi siswa dalam proses pembelajaran. Karakter dasar siswa yang rata-rata baik, sehingga dapat menyesuaikan diri dengan model pendidikan karakter di MAN 1 Boyolali. Kurikulum pendidikan yang mendukung pendidikan karakter di MAN 1 Boyolali. Budaya demokratis yang mendukung pendidikan karakter yang menjadi kebiasaan di kelas, lingkungan sekolah dan komunitas sekolah meliputi komite sekolah, orang tua siswa, dan alumni.

Faktor penghambat implementasi pendidikan karakter pada siswa di MAN I Boyolali, yaitu pengaruh negatif dari lingkungan pergaulan siswa di luar sekolah. Budaya "Nurun" masih sangat tinggi, tanpa tahu asal muasal cara penyelesaiannya. Banyaknya tugas yang harus diselesaikan siswa setiap harinya, baik tugas akademik maupun tugas organisasi intrakurikuler maupun ekstrakurikuler. Penyalahgunaan HP dan gadget di lingkungan kelas dan sekolah. Kurangnya kesempatan untuk saling berkomunikasi dan koordinasi antara pihak sekolah dengan komite sekolah, orang tua siswa, dan alumni. 


\section{DAFTAR PUSTAKA}

Abdul Majid dan Dian Andayani. Pendidikan Karakter Perspektif Islam. Bandung: Remaja Rosdakarya

Badrus Zaman. 2018. Pendidikan Akhlak pada Anak Jalanan di Surakarta. Jurnal Inspirasi Vol. 2 No. 2 Undaris Ungaran.

Badrus Zaman. 2019. Urgensi Pendidikan Karakter yang sesuai dengan Falsafah Bangsa Indonesia. Jurnal Al Ghazali Vol. 2 No. 1 STAINU Purworejo.

Darmiati Zuchdi, dkk. 2012. Pendidikan Karakter Konsep Dasar dan Implementasi di Perguruan Tinggi. Yogyakarta: UNY Press

Doni Koesoema A. 2012. Pendidikan Karakter Utuh dan Menyeluruh. Yogyakarta: Kanisius

Lexy J. Moleong. 2010. Metodologi Penelitian Kualitatif. Bandung: PT Remaja Rosdakarya.

Muchlas Samani \& Hariyanto. 2011. Konsep dan Model Pendidikan Karakter. Bandung: PT. Remaja Rosdakarya.

Muchlas Samani \& Hariyanto. 2012. Konsep dan Model Pendidikan Karakter. Bandung: Remaja Rosdakarya

Thomas Lickona. 2013. Educating for Character: Mendidik untuk Membentuk Karakter. Jakarta: Bumi Aksara

Ulil Amri Syarif. 2012. Pendidikan Karakter Berbasis Al-Qur'an. Jakarta: Raja Grafindo Press

Undang-Undang RI No 20. 2003. Tentang Sistem Pendidikan Nasional. Jakarta: Cipta Jaya 